\title{
Determination of Temporary Shelter Areas by the Analytic Hierarchy Process Method: The Case of Burdur City Center, Turkey
}

\author{
Hüseyin Samet Aşıkkutlu ${ }^{1, a, *}$, Yasin Aşık ${ }^{1, b}$, Latif Gürkan Kaya ${ }^{1, c}$ \\ ${ }^{1}$ Department of Landscape Architecture, Faculty of Engineering and Architecture, Burdur Mehmet Akif Ersoy University, 15030 Burdur, Turkey \\ *Corresponding author \\ A R T I C L I N F O A B S T R A C T \\ Research Article \\ Disasters adversely affect human life. Many people face sheltering problems after disasters. \\ Temporary shelter areas are very important in terms of meeting people's post-disaster sheltering \\ needs. In this study, it was aimed to determine temporary shelter areas in the city center of Burdur. \\ The AHP (Analytic Hierarchy Process) method was used to determine temporary shelter areas. \\ Received : 09/02/2021 \\ Accepted : 18/02/2021 \\ According to certain criteria and spatial standards, six temporary shelter areas were determined in \\ the city center of Burdur, and their adequacy was tested. Temporary shelters are located in urban \\ open and green lands. Temporary shelter areas determined under today's conditions are adequate. \\ However, it is predicted that temporary shelter areas will be inadequate in the upcoming process. \\ Some recommendations were made about the problems and the path to be followed in the upcoming \\ Keywords: \\ process. These recommendations will be useful for the post-disaster process.
}

Analytic hierarchy process Burdur

Disaster

Geographic information systems

Temporary shelter areas

sasikkutlu@mehmetakif.edu.tr (iD) https://orcid.org/0000-0002-3518-7202

lgkaya@mehmetakif.edu.tr $\quad$ (i) https://orcid.org/0000-0001-8033-1480

b@yasik@mehmetakif.edu.tr

iD https://orcid.org/0000-0002-4332-9776

(c) (1) (9) This work is licensed under Creative Commons Attribution 4.0 International License

\section{Introduction}

Urbanization is gradually increasing (Pickett et al., 2008; Ramalho and Hobbs, 2012; Cetin, 2020), and nowadays, $55 \%$ of the world population lives in cities, and this ratio is estimated to increase gradually (UN, 2018). Along with the effect of population increase and globalization, cities further lose their resistance to natural disasters (Desouza, 2013). In this disaster causes to the effects of some natural resources such as water quality as weel as chosing the place (Mutlu and Güzel, 2019; Emin et al., 2020). In natural disasters that took place in the world between 2000 and 2020, while the loss of life increased by $2.5 \%$, the number of people affected increased by $21 \%$, and economic damage increased by $67 \%$ compared to years 1980-1999 (EM-DAT, 2021).

After disasters, many people are adversely affected. For example, they become homeless. People whose houses are destroyed or damaged and who have to leave their living area mostly face sheltering problems (Tanyaş et al., 2013). Pre-determined safe areas should be reserved as temporary shelter areas for disaster victims (Özbay et al., 2019). Urban open and green lands are important for the quality of life of people in cities (La Rosa, 2014; Mougiakou and Photis, 2014) and also serve as temporary shelter areas for people after an earthquake (Allan and Bryant, 2011; Anhorn and Khazai, 2015; Zhu et al., 2016). Furthermore, disaster resilience in relation to the environmental, social, and economic sustainability of urban open and green lands takes an important place in the literature (Jayakody et al., 2018). While planning urban open and green lands suitable for postdisaster use, it is necessary to meet the access, quality, and safety criteria (Li et al., 2013; Kırçın et al., 2017).

In the literature, different methods were adopted for the determination of open and green lands to be used as temporary shelter areas after disasters. The AHP (Analytic Hierarchy Process) method (Turgut et al., 2011; Napi and Souza, 2015; Nappi et al., 2019; Gökgöz et al., 2020; Kim et al., 2020), one of the multi-criteria decision-making methods (MCDM), and the methods used by integrating AHP into GIS (Geographic Information Systems) (Şentürk and Erener; 2017; Junian and Azizifar, 2018; Jahangiri et al., 2019) are currently used by researchers for the determination and evaluation of temporary shelter areas. 
There are 56 emergency assembly areas determined in the city center of Burdur (AFAD, 2021). In their study, Aş1kkutlu et al. (2021) examined the adequacy of the existing emergency assembly areas in the city center of Burdur. Nevertheless, the location and adequacy of temporary shelter areas, which are of great importance after disasters, are still uncertain.

The aim of this study was to determine temporary shelter areas to be used in case of a possible disaster in the city center of Burdur and to test their adequacy. In this context, seven basic criteria and spatial standards in the literature were mentioned in the location selection of temporary shelter areas. Temporary shelter areas were determined by considering the mentioned criteria and spatial standards, the adequacy of the use of open and green lands in the city center of Burdur as temporary shelter areas was tested, and some recommendations were made.

\section{Materials and Methods}

The city center of Burdur constituted the study area. The city center of Burdur is located between $30^{\circ} 11^{\prime}-30^{\circ}$ $21^{\prime}$ east longitudes and $37^{\circ} 41^{\prime}-37^{\circ} 46^{\prime}$ north latitudes (Figure 1). Burdur is surrounded by Isparta in the east, Denizli in the west, Afyonkarahisar in the north, and Antalya in the south. The city center consists of 35 neighborhoods and has a population of 92670 (TÜIK, 2020).

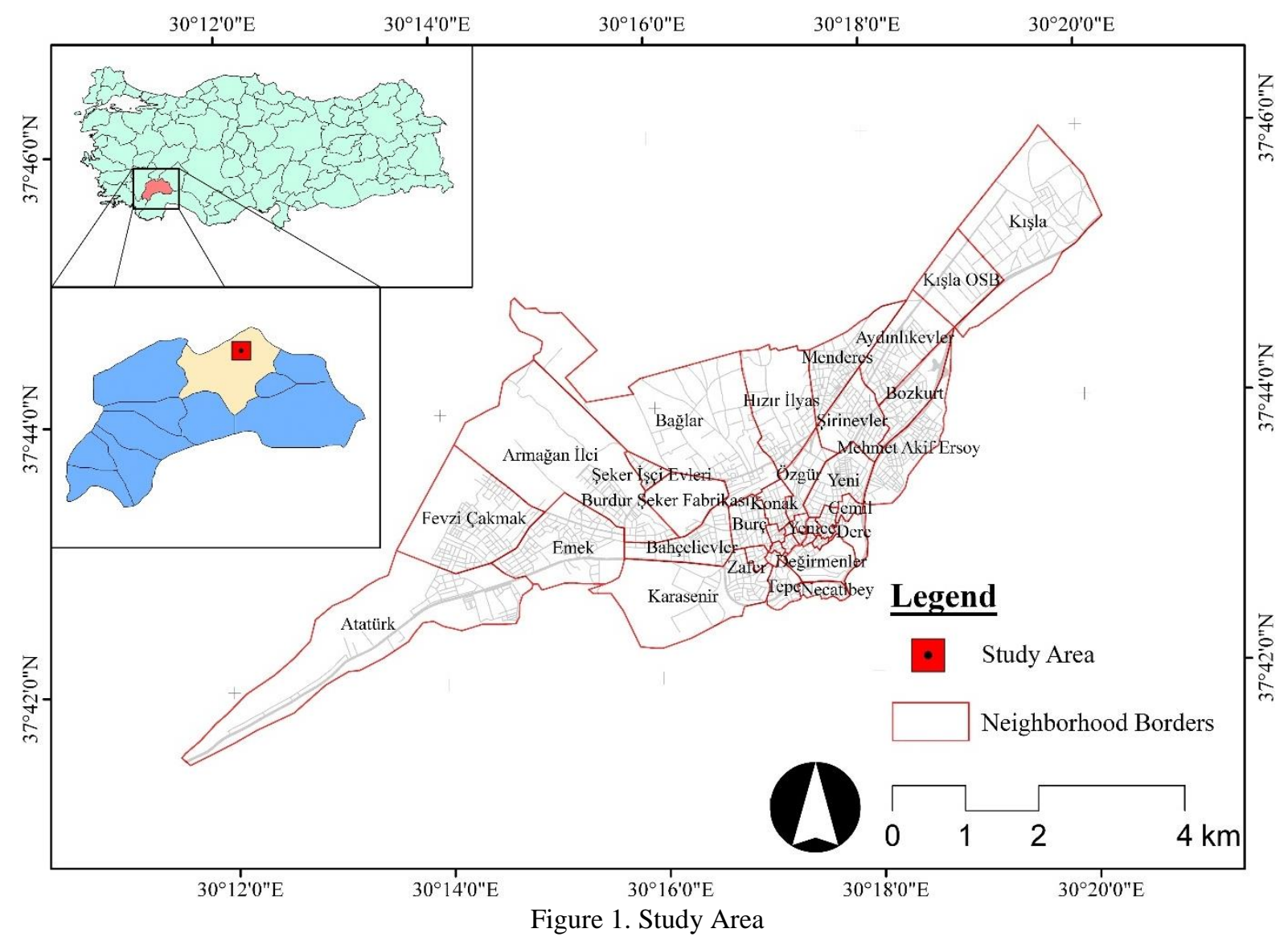

The literature was comprehensively reviewed for the location selection of temporary shelter areas. As a result of the review, many location selection suitability criteria were determined from the relevant sources. The criteria determined were adapted to the city center of Burdur. According to the classification range, the criteria were scored as 5 "Very Suitable," 4 "Suitable," 3 "Moderately Suitable," 2 "Unsuitable," and 1 "Highly Unsuitable" (Table 2).

The AHP method, one of the multi-criteria decisionmaking methods, was used in the determination of criteria weights (Saaty, 1980; Saaty, 1987). The analytic hierarchy process is one of the techniques that are used to make decisions in the solution of complex problems involving different factors (Saaty, 1980; Dou et al., 2017) and also combine qualitative and quantitative analysis in the solution of these problems (Kordi et al., 2012). The AHP method was applied in accordance with the following process.

The pairwise comparison matrix (A) was created as in Equation 1 to determine the significance of the criteria (Hoang et al., 2018). The pairwise comparison scale indicated in Table 1 was used for the comparison of criteria. According to Hoang et al. (2018), this scale enables converting qualitative and quantitative elements into numerical values.

$$
A=\left[\begin{array}{cccc}
a_{11} & a_{12} & \ldots & a_{1 n} \\
a_{21} & a_{22} & \ldots & a_{2 n} \\
\cdot & & & \cdot \\
\cdot & & & \cdot \\
\cdot & & & \cdot \\
a_{n 1} & a_{n 2} & \ldots & a_{n n}
\end{array}\right]
$$


Table 1. Pairwise Comparison Scale (Saaty, 1980; Hoang et al., 2018)

\begin{tabular}{l|l}
\hline \multicolumn{1}{c|}{ Value of importance } & \multicolumn{1}{c}{ Definition } \\
\hline 1 & Equal importance \\
3 & Moderate importance \\
5 & Strong importance \\
7 & Very strong importance \\
9 & Extreme importance \\
\hline $2,4,6,8$ & Intermediate values \\
\hline
\end{tabular}

Table 2. Basic location selection suitability criteria and criteria weights for temporary shelter areas*

\begin{tabular}{|c|c|c|c|}
\hline Criteria & $\begin{array}{c}\text { Classification } \\
\text { Range }\end{array}$ & Score & $\begin{array}{l}\text { Criteria } \\
\text { Weights }\end{array}$ \\
\hline $\begin{array}{l}\text { Distance to } \\
\text { health facilities } \\
\text { and fire stations }\end{array}$ & $\begin{array}{c}<1000 \mathrm{~m} \\
1000-1500 \mathrm{~m} \\
1500-2000 \mathrm{~m} \\
2000-2500 \mathrm{~m} \\
>2500 \mathrm{~m}\end{array}$ & $\begin{array}{l}5 \\
4 \\
3 \\
2 \\
1\end{array}$ & $37 \%$ \\
\hline $\begin{array}{l}\text { Distance to } \\
\text { flood regions }\end{array}$ & $\begin{array}{l}>500 \mathrm{~m} \\
<500 \mathrm{~m}\end{array}$ & $\begin{array}{l}5 \\
1\end{array}$ & $15 \%$ \\
\hline $\begin{array}{l}\text { Distance to } \\
\text { fueling stations }\end{array}$ & $\begin{array}{l}>100 \mathrm{~m} \\
<100 \mathrm{~m}\end{array}$ & $\begin{array}{l}5 \\
1\end{array}$ & $14 \%$ \\
\hline $\begin{array}{l}\text { Distance to fault } \\
\text { lines }\end{array}$ & $\begin{array}{c}>1500 \mathrm{~m} \\
1000-1500 \mathrm{~m} \\
500-1000 \mathrm{~m} \\
250-500 \mathrm{~m} \\
<250 \mathrm{~m}\end{array}$ & $\begin{array}{l}5 \\
4 \\
3 \\
2 \\
1\end{array}$ & $15 \%$ \\
\hline $\begin{array}{l}\text { Distance to } \\
\text { emergency } \\
\text { assembly areas }\end{array}$ & $\begin{array}{c}<1000 \mathrm{~m} \\
1000-1500 \mathrm{~m} \\
1500-2000 \mathrm{~m} \\
2000-2500 \mathrm{~m} \\
>2500 \mathrm{~m}\end{array}$ & $\begin{array}{l}5 \\
4 \\
3 \\
2 \\
1\end{array}$ & $8 \%$ \\
\hline $\begin{array}{l}\text { Distance to } \\
\text { main roads }\end{array}$ & $\begin{array}{c}<500 \mathrm{~m} \\
500-1500 \mathrm{~m} \\
>1500 \mathrm{~m}\end{array}$ & $\begin{array}{l}5 \\
3 \\
1\end{array}$ & $8 \%$ \\
\hline $\begin{array}{l}\text { Slope of the } \\
\text { area }\end{array}$ & $\begin{array}{c}2-4 \% \\
4-7 \% \text { ve } 0-2 \% \\
>7 \%\end{array}$ & $\begin{array}{l}5 \\
3 \\
1\end{array}$ & $3 \%$ \\
\hline $\mathrm{CI}=0.10 ; \mathrm{RI}=1$. & $\lambda \max =7.59 ; C$ & $07<$ & \\
\hline
\end{tabular}

*(UNHCR, 2007; Baradran-Shoraka, 2009; Liu et al., 2011; Anhorn and Khazai, 2015; Kılc1 et al., 2015; Taylor et al., 2016; Ünal and Uslu, 2016; Deliry and Uyguçgil, 2020)

The calculation of criteria weights is the next step after the pairwise comparison matrix is created. The eigenvector method of Saaty in Equation 2, which is the best method (Hurley, 2001), was used for the calculation of criteria weights (Ramadhan et al., 1999).

$$
\mathrm{W}_{\mathrm{i}}=\frac{1}{\mathrm{n}} \sum_{\mathrm{j}=1}\left[\frac{\mathrm{a}_{\mathrm{ij}}}{\sum_{\mathrm{j}=1}^{\mathrm{n}} \mathrm{a}_{\mathrm{ij}}}\right]
$$

AHP allows a certain degree of inconsistency in data. The consistency of the comparison matrix is determined by the CR (consistency ratio) and calculated using Equation 3. The CR must be $<0.10$ so that the comparison matrix can be applied. CI and RI refer to consistency index and random index, respectively. When there are 7 criteria, RI takes the value of $=1.32$ (Saaty, 1980). The criteria weights determined are presented in Table 2 . Since the $\mathrm{CR}$ value was $0.07<0.10$, the criteria weights determined were applied in the location selection.

$$
\mathrm{CR}=\frac{\mathrm{CI}}{\mathrm{RI}}
$$

In the pairwise comparison matrix, the CI for the criterion $\mathrm{n}$ is calculated as follows (Equation 4) (Saaty, 1980).

$$
\mathrm{CI}=\frac{\lambda_{\max }-\mathrm{n}}{\mathrm{n}-1}
$$

While calculating the CI value, the $\lambda_{\max }$ value in the formula is calculated using the following formula (Peng and Dai, 2009).

$$
\lambda_{\max }=\frac{1}{\mathrm{n}} \sum_{\mathrm{i}=1}^{\mathrm{n}} \frac{(\mathrm{AW})_{\mathrm{i}}}{\mathrm{W}_{\mathrm{i}}}
$$

The distances of location selection suitability criteria were calculated by performing buffer analysis in ArcMap 10.8 program. For the buffer analysis, main roads, health and fire facilities, flood risk streams and fueling stations (Anonymous, 2020a), fault lines (MTA, 2020) and emergency assembly areas (AFAD, 2020) were determined and digitized. The contour lines spaced 25 meters apart (Anonymous, 2020b) were used to calculate the slope of the area. The "WGS84 UTM Zone 35" coordinate system was used in the study.

The weighted location selection suitability map was obtained by overlaying the maps obtained by performing buffer analysis and calculating the slope of the area using the "Weighted Overlay" tool in the ArcMap 10.8 program. An area of $20000 \mathrm{~m}^{2}$ as the spatial standard and an area size of $2 \mathrm{~m}^{2}$ (Zhu et al., 2016) were taken as a basis for temporary shelter areas. Based on the weighted location selection suitability map and spatial standards, location selection was performed for temporary shelter areas, and their adequacy was tested.

\section{Results and Discussion}

The classified location selection suitability maps and the weighted location selection suitability map belonging to 7 basic criteria used in the location selection of temporary shelter areas are presented in Figure 2. In the criteria classified according to the figure, very suitable and moderately suitable classes were predominant. In the map overlaying procedure performed by considering the criteria weights for the determination of temporary shelter areas, it was determined that the city center of Burdur mostly included suitable and moderately suitable areas (Figure $2 \mathrm{~h}$ ).

The class sizes in the weighted location selection suitability map are presented in Table 3 . According to the table, "Suitable Class" had the most area (1898.43 ha). This value corresponds to $68.1 \%$ of the area size of the city center of Burdur. The Suitable Class was followed by the "Moderately Suitable Class" with 729.64 ha (26.2\%). "Unsuitable Classes" (Unsuitable, Highly Unsuitable) had the lowest value with 33.43 ha (1.2\%). 
a

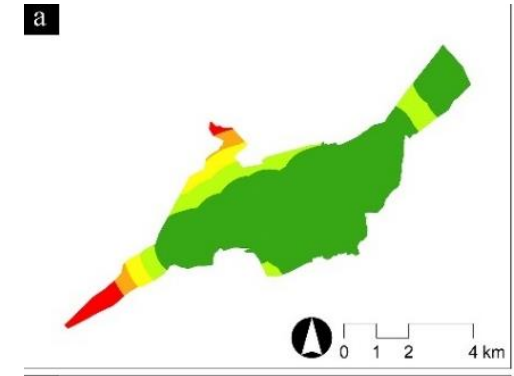

d

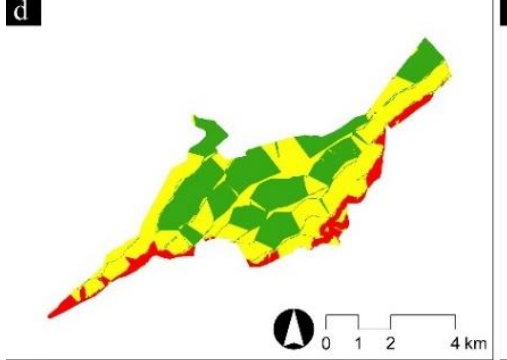

g

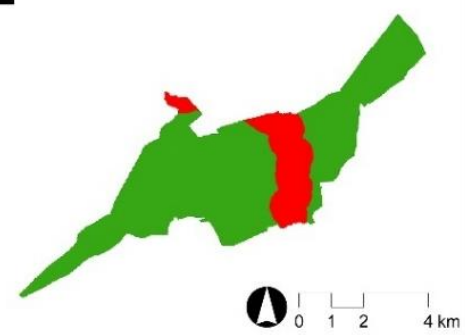

b

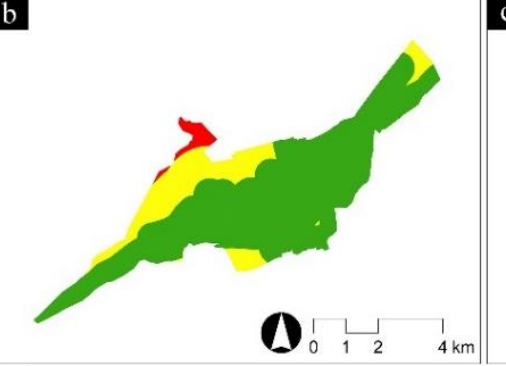

e

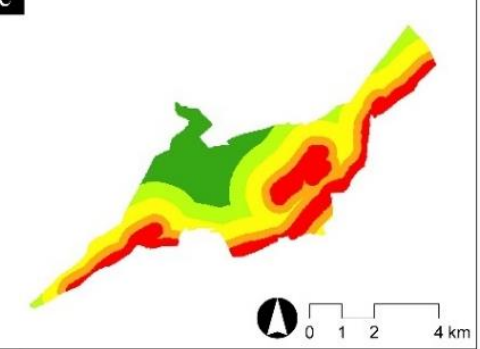

h

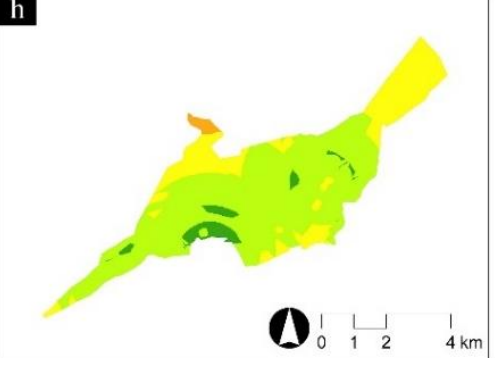

c

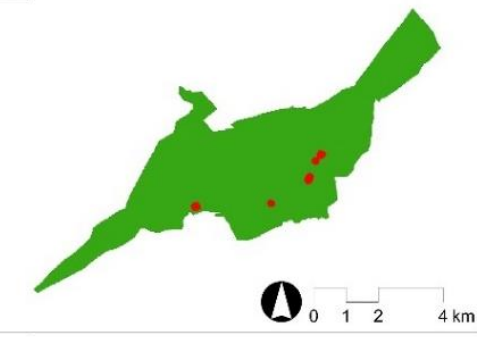

f

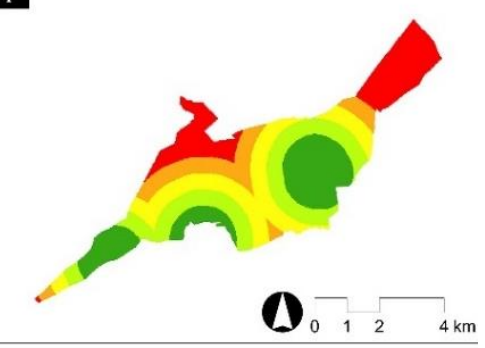

\section{Legend}

Suitability

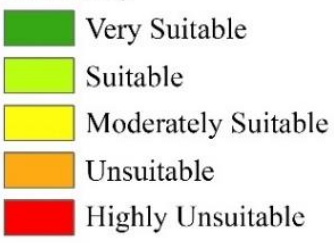

Figure 2. Suitability maps (a) distance to emergency assembly areas, (b) distance to main roads, (c) distance to fueling stations, (d) slope of the area, (e) distance to fault lines, (f) distance to health facilities and fire stations, (g) distance to flood regions, (h) weighted location selection

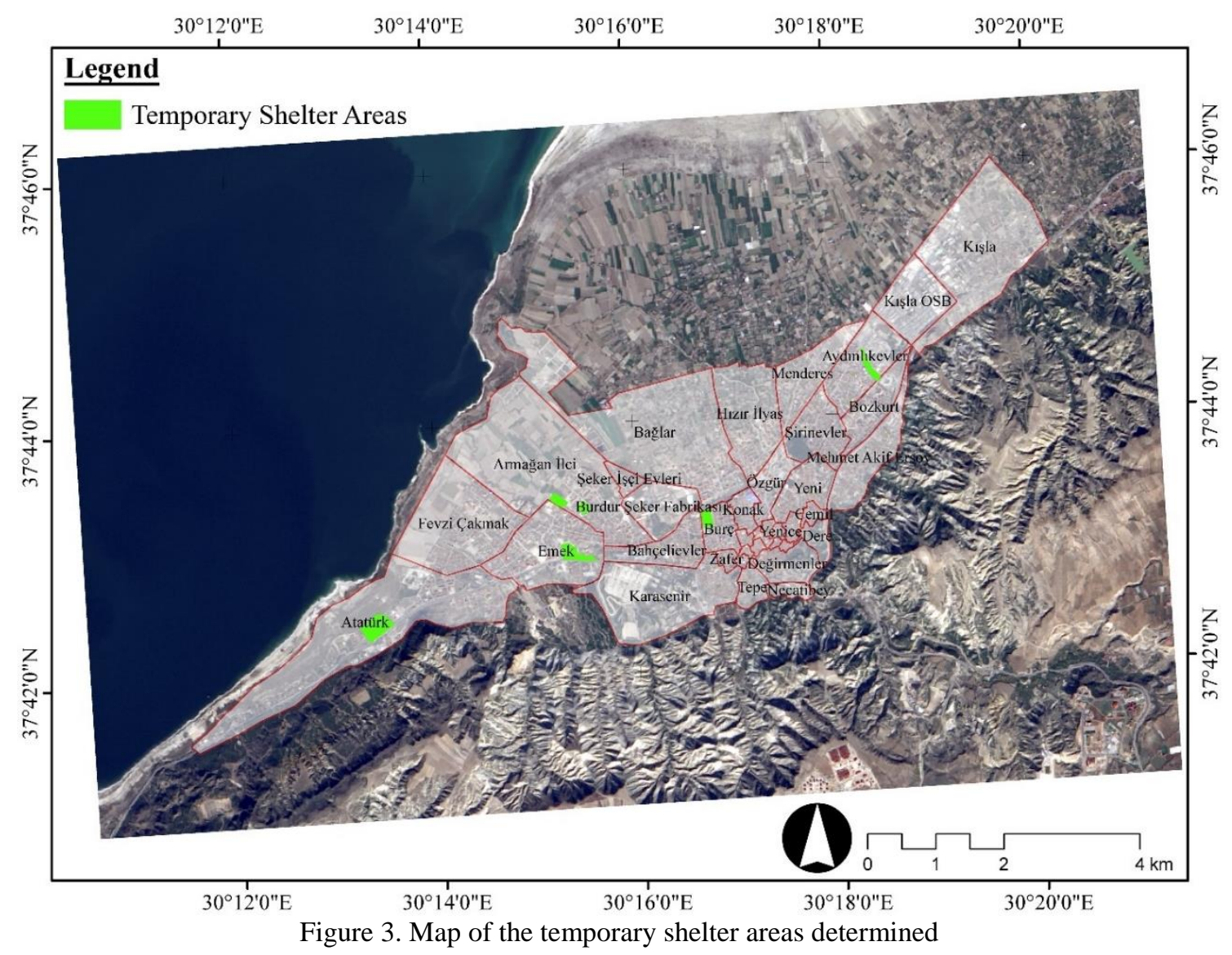


Table 3. Class sizes in the weighted location selection suitability map

\begin{tabular}{l|cc}
\multicolumn{1}{c|}{ Class } & Area (ha) & Area (\%) \\
\hline Very Suitable & 124.62 & 4.5 \\
Suitable & 1898.43 & 68.1 \\
Moderately Suitable & 729.64 & 26.1 \\
Unsuitable & 33.43 & 1.2 \\
Highly Unsuitable & 0 & 0 \\
Total & 2786.12 & 100 \\
\hline
\end{tabular}

Table 4. Location and area sizes of the determined temporary shelter areas

\begin{tabular}{l|ccc}
\hline \multicolumn{1}{c|}{ Neighborhoods } & No & Location & Area $\left(\mathrm{m}^{2}\right)$ \\
\hline Armağan İlci & 1 & $37^{\circ} 43^{\prime} 23^{\prime \prime} \mathrm{N}-30^{\circ} 15^{\prime} 13^{\prime \prime} \mathrm{E}$ & 28049.37 \\
& 2 & $37^{\circ} 43^{\prime} 20^{\prime \prime} \mathrm{N}-30^{\circ} 15^{\prime} 29^{\prime \prime} \mathrm{E}$ & 20979.47 \\
Atatürk & 1 & $37^{\circ} 42^{\prime} 26^{\prime \prime} \mathrm{N}-30^{\circ} 13^{\prime} 23^{\prime \prime} \mathrm{E}$ & 108977.00 \\
Aydınlıkevler & 1 & $37^{\circ} 44^{\prime} 21^{\prime \prime} \mathrm{N}-30^{\circ} 18^{\prime} 22^{\prime \prime} \mathrm{E}$ & 35047.18 \\
Burç & 1 & $37^{\circ} 43^{\prime} 122^{\prime \prime} \mathrm{N}-30^{\circ} 16^{\prime} 43^{\prime \prime} \mathrm{E}$ & 33452.39 \\
Emek & 1 & $37^{\circ} 42^{\prime} 58^{\prime \prime} \mathrm{N}-30^{\circ} 15^{\prime} 20^{\prime \prime} \mathrm{E}$ & 64505.30 \\
Urban Center (Total) & 6 & & 291010.7 \\
\hline
\end{tabular}

Table 5. Population of the city center of Burdur between 2014-2019, population forecast between 2020-2025, and temporary shelter area per person

\begin{tabular}{|c|c|c|c|c|c|c|}
\hline \multirow[b]{2}{*}{ Years } & \multicolumn{2}{|c|}{ 2014-2019 Population (TÜİK, 2020) } & \multirow[b]{2}{*}{ Years } & \multicolumn{2}{|c|}{ 2020-2025 Population Forecast } & \multirow{2}{*}{$\begin{array}{c}\text { Estimation of } \\
\text { Temporary Shelter } \\
\text { Areas }\left(\mathrm{m}^{2}\right)\end{array}$} \\
\hline & Population & $\begin{array}{c}\text { Growth Rate } \\
(\%)\end{array}$ & & Population & $\begin{array}{c}\text { Growth Rate } \\
(\%)\end{array}$ & \\
\hline 2014 & 75460 & - & 2020 & 96377 & 4 & 3.02 \\
\hline 2015 & 78331 & 3.67 & 2021 & 100232 & 4 & 2.90 \\
\hline 2016 & 81559 & 3.96 & 2022 & 104241 & 4 & 2.79 \\
\hline 2017 & 85312 & 4.40 & 2023 & 108411 & 4 & 2.68 \\
\hline 2018 & 90303 & 5.53 & 2024 & 112747 & 4 & 2.58 \\
\hline 2019 & 92670 & 2.55 & 2025 & 117257 & 4 & 2.48 \\
\hline
\end{tabular}

Based on the weighted location selection suitability map, spatial standards and zoning plan, six urban open and green lands in the city center of Burdur were determined as temporary shelter areas through the satellite image (Landsat 8). All of the selected temporary shelter areas are located in the areas in the suitable class (Figure 3 ).

In this study, only public open and green lands (park, playground, market place, sport lands, squares, etc.) were used in the selection of temporary shelter areas. The area selection was quite difficult while determining temporary shelter areas, and selection could be performed only in 6 areas, the reasons for which were an unsuitable area size of open green lands in the city center, highly fragmented open green lands, and construction and agricultural activities in the areas specified as open green lands (park, playground, etc.) in the zoning plan.

Furthermore, the service radius was not taken into account while determining temporary shelter areas in this study. As the first activity during disasters, people gather in emergency assembly areas (Gerdan and Şen, 2019). Then, people are evacuated from emergency assembly areas to temporary shelter areas (Çınar et al., 2018). Therefore, the location selection in temporary shelter areas was based on their proximity to emergency assembly areas rather than the service radius.

The location and area sizes of the determined temporary shelter areas are presented in Table 4. Armağan İci was the neighborhood with the highest number of temporary shelter areas (2). Nevertheless, in terms of the size of the area, the largest temporary shelter area was selected in Atatürk neighborhood. Six temporary shelter areas with a total size of $291010.70 \mathrm{~m}^{2}$ were determined in the city center of Burdur. According to the temporary shelter areas determined, there was an area of $3.14 \mathrm{~m}^{2}$ (291010.7 $\mathrm{m}^{2} / 92670$ people) per person in the city center of Burdur. This ratio is adequate, as stated in the literature.

The population of the city center of Burdur between 2014-2019, population forecast between 2020-2025, and the estimation of temporary shelter areas per person between 2020-2025 are presented in Table 5. The population growth rate between 2020-2025 was obtained by taking the average of the increase between 2014-2019. According to this table, temporary shelter areas determined in parallel with the population growth rate are under the threat of being inadequate in the upcoming process.

\section{Conclusion}

Temporary shelter areas are usually established after the occurrence of disasters. In the chaos that occurs after a disaster, the selection of suitable areas for temporary shelter areas will be difficult and will delay the aids. Therefore, location selections should be made for temporary shelter areas before disasters. In this study, it was indicated that six urban open and green lands as temporary shelter areas in the city center of Burdur were suitable for location selection. In the specified areas, infrastructure service (electricity, water, etc.) should always be available in case of a potential disaster.

Open and green lands in the city center of Burdur are currently adequate to be used as temporary shelter areas. However, if open and green lands that can be used as 
temporary shelter areas are not increased depending on the population growth rate in the upcoming periods, temporary shelter areas will be inadequate. Urban open and green lands that can be used as temporary shelter areas should be increased. Furthermore, it is predicted that open and green lands will be lost, fragmented and cannot be created according to the current planning approach in parallel with the population growth in the future. Local administrations should change the current planning approach and adopt an understanding of the creation of urban open and green lands that can be used as temporary shelter areas.

In this study, the actions to be taken to be prepared against disasters that may occur in the city of Burdur were indicated. The measures mentioned may create a framework for local administrations. It is thought that the consideration of the specified recommendations will contribute to the reduction of loss of life, rapid delivery of aid and prevention of chaos in the city center of Burdur.

\section{References}

AFAD, 2020. Afet ve Acil Durum Yönetimi Başkanlığı. Acil Toplanma Alan1 Sorgulama. Avaible from: https://www.turkiye.gov.tr/afet-ve-acil-durum-yonetimiacil- toplanma-alani-sorgulama [Accessed 20 September 2020]

Allan P, Bryant M. 2011. Resilience as a framework for urbanism and recovery. Journal on Landscape Architecture, 6: 34-45. doi:10.1080/18626033.2011.9723453

Anhorn J, Khazai B. 2015. Open space suitability analysis for emergency shelter after an earthquake. Natural Hazards and Earth System Sciences, 15: 789-803. doi:10.5194/nhess-15789-2015

Anonymous, 2020a. Google Earth. Avaible from: https://www.google.com/earth/ [Accessed 20 November 2020]

Anonymous, 2020b. OpenDem. Download SRTM based Contour Lines. Avaible from: https://www.opendem.info/ download_contours.html [Accessed 20 November 2020]

Aşskkutlu HS, Aşık Y, Yücedağ C, Kaya LG. 2021. Determination of adequacy of ermegency assembly areas for Burdur city at the neigborhood scale in case of potential earthquakes. Mehmet Akif Ersoy University Journal of Economics and Administrative Sciences Faculty, 8(1): In Press.

Baradran-Shoraka M. 2009. Site Selection of Temporary Shelter for Municipality District No.1 of Tehran Based on Damage Assessment (in Persian). Thesis submitted for the degree of Master of Science in Natural Disaster Management. Graduate Faculty of Environment, University of Tehran, Iranian.

Cetin M. 2020. The changing of important factors in the landscape planning occur due to global climate change in temperature, Rain and climate types: A case study of Mersin City. Turkish Journal of Agriculture-Food Science and Technology, 8(12): 2695-2701.

Çınar AK, Akgün Y, Maral H. 2018. Analyzing the planning criteria for emergency assembly points and temporary shelter areas: Case of İzmir-Karsiyaka. Planning, 28(2):179-200. doi: 10.14744/planlama.2018.07088

Deliry Sİ, Uyguçgil H. 2020. GIS-Based land suitability analysis for sustainable urban development: A case study in Eskisehir, Turkey. Afyon Kocatepe University Journal of Science and Engineering, 20(4): 634-650. doi: 10.35414/akufemubid. 679980

Desouza KC, Flanery TH. 2013. Designing, planning, and managing resilient cities: A conceptual framework. Cities, 35: 89-99. doi: 10.1016/j.cities.2013.06.003
Dou X, Song J, Wang L, Tang B, Xu S, Kong F, Jiang X. 2018. Flood risk assessment and mapping based on a modified multi-parameter flood hazard index model in the Guanzhong Urban Area, China. Stochastic Environmental Research and Risk Assessment, 32: 1131-1146. doi: 10.1007/s00477-0171429-5

Emin N, Mutlu E, Güzel AE. 2020. Determination the effectiveness of the cytotoxic analysis on the water quality assessments. Turkish Journal of Agriculture-Food Science and Technology, 8(2): 478-483.

EM-DAT, (2021). The International Disaster Database. Avaible from: https://public.emdat.be/ [Accessed 11 January 2021]

Gerdan S, Şen A. 2019. Evaluation of qualifications of assembly points for disaster and emergency: Case of Kocaeli, Izmit. İdealkent, 10(28): 962-983. doi: 10.31198/idealkent.514077

Gökgöz Bİ, İlerisoy ZY, Soyluk A. 2020. Evaluation of emergency shelter areas with the AHP method. European Journal of Science and Technology, (19): 935-945. doi: 10.31590/ejosat.739544

Hoang HTT, Truong, QH, Nguyen AT, Hens L. 2018. Multicriteria evaluation of tourism potential in the central highlands of Vietnam: Combining geographic information system (GIS), analytic hierarchy process (AHP) and principal component analysis (PCA). Sustainability, 10: 3097. doi: $10.3390 /$ su10093097

Hurley WJ. 2001. The analytic hierarchy process: a note on an approach to sensitivity which preserves rank order. Computers \& Operations Research, 28(2): 185-188. doi: 10.1016/s0305-0548(99)00125-2

Jahangiri K, Borgheipour $\mathrm{H}$, Gendeshmin SB, Matin A, Monazami Tehrani G. 2019. Site selection criteria for temporary sheltering in urban environment. International Journal of Disaster Resilience in the Built Environment, 11: 58-70. doi: 10.1108/ijdrbe-06-2018-0025

Jayakody RRJC, Amarathunga D, Haigh R. 2018. Integration of disaster management strategies with planning and designing public open spaces. Procedia Engineering, 212: 954-961. doi: 10.1016/j.proeng.2018.01.123

Junian J, Azizifar V. 2018. The evaluation of temporary shelter areas locations using geographic information system and analytic hierarchy process. Civil Engineering Journal, 4(7): 1678-1688. doi: 10.28991/cej-03091104

Kılc1 F, Kara BY, Bozkaya B. 2015. Locating temporary shelter areas after an earthquake: A case for Turkey. European Journal of Operational Research, 243: 323-332. doi: 10.1016/j.ejor.2014.11.035

Kırçın PN, Çabuk SN, Aksoy K, Çabuk A. 2017. Ülkemizde yeşil alanların afet sonrası toplanma alanı olarak kullanılma olanaklarının artırılması üzerine bir araştırma, 4. Uluslararası deprem Mühendisliği ve Sismoloji Konferansı, Anadolu Üniversitesi, Eskişehir, 11-13 Ekim 2017. Avaible from: http://www.tdmd.org.tr/TR/Genel/4UDMSK/pdf2017/3843. pdf [Accessed 25 September 2020]

Kim N, Joo J, Kim M, Park K. 2020. Development of a multicriteria evaluation framework and its application for earthquake shelter selection. Journal of the Korean Society of Hazard Mitigation, 20: 197-205. doi: 10.9798/kosham.2020.20.2.197

Kordi M, Brandt SA. 2012. Effects of increasing fuzziness on analytic hierarchy process for spatial multicriteria decision analysis. Computers, Environment and Urban Systems, 36: 43-53. doi: 10.1016/j.compenvurbsys.2011.07.004

La Rosa D. 2014. Accessibility to greenspaces: GIS based indicators for sustainable planning in a dense urban context. Ecological Indicators, 42: 122-134. doi: 10.1016/j.ecolind.2013.11.011.

Li Y, Liu Y, Jiao J. 2013. A GIS-based suitability analysis of Xiamen's green space in park for earthquake disaster prevention and refuge. Urban Planning and Design Research, 1(1): 1-8. 
Liu Q, Ruan X, Shi P. 2011. Selection of emergency shelter sites for seismic disasters in mountainous regions: Lessons from the 2008 Wenchuan Ms 8.0 Earthquake, China. Journal of Asian Earth Sciences, 40: 926-934. doi: 10.1016/j.jseaes.2010.07.014

Mougiakou E, Photis YN. 2014. Urban green space network evaluation and planning: Optimizing accessibility based on connectivity and raster gis analysis. European Journal of Geography, 5(4): 19-46.

Mutlu E, Güzel AE. 2019. Evaluation of some physicochemical water quality parameters of Gümüşsuyu Pond (SinopErfelek). Turkish Journal of Agriculture-Food Science and Technology, 7(sp3): 72-77.

MTA, 2020. Maden Tetkik ve Arama Genel Müdürlügü. Yerbilimleri harita görüntüleyici ve çizim editörü. Avaible from: http://yerbilimleri.mta.gov.tr/anasayfa.aspx [Accessed 20 September 2020]

Nappi MML, Nappi V, Souza JC. 2019. Multi-criteria decision model for the selection and location of temporary shelters in disaster management. Journal of International Humanitarian Action, 4(1): 16. doi:10.1186/s41018-019-0061-z

Nappi MML, Souza JC. 2015. Disaster management: hierarchical structuring criteria for selection and location of temporary shelters. Natural Hazards, 75(3): 2421-2436. doi: 10.1007/s11069-014-1437-4

Ozbay E, Çavuş Ö, Kara BY. 2019. Shelter site location under multi-hazard scenarios. Computers \& Operations Research, 106: 102-118. doi: 10.1016/j.cor.2019.02.008

Peng X, Dai F. 2009. Information systems risk evaluation based on the AHP-fuzzy algorithm. In 2009 International Conference on Networking and Digital Society, 2: 178-180. doi: 10.1109/icnds.2009.124

Pickett STA, Cadenasso ML, Grove JM, Groffman PM, Band LE, Boone CG, Burch WR, Grimmond CSB, Hom J, Jenkins JC, Law NL, Nilon CH, Pouyat RV, Szlavecz K, Warren PS, Wilson MA. 2008. Beyond urban legends: an emerging framework of urban ecology, as illustrated by the baltimore ecosystem study. BioScience, 58: 139-150. doi: $10.1641 / \mathrm{b} 580208$

Ramadhan RH, Al-Abdul Wahhab HI, Duffuaa SO. 1999. The use of an analytical hierarchy process in pavement maintenance priority ranking. Journal of Quality in Maintenance $\quad$ Engineering, 5: 25-39. doi:10.1108/13552519910257041

Ramalho CE, Hobbs RJ, 2012. Time for a change: dynamic urban ecology. Trends in Ecology \& Evolution, 27: 179-188. doi: 10.1016/j.tree.2011.10.008
Saaty RW. 1987. The analytic hierarchy process-what it is and how it is used. Mathematical Modelling, 9: 161-176. doi: 10.1016/0270-0255(87)90473-8

Saaty TL. 1980. The Analytic Hierarchy Process: Planning, Priority Setting, Resource Allocation (Decision Making Series). New York: McGraw-Hill. ISBN: 978-0070543713.

Şentürk E, Erener A. 2017. Determination of temporary shelter areas in natural disasters by gis a case study for Gölcük/Turkey. International Journal of Engineering and Geosciences, 2: 84-90. doi: 10.26833/ijeg.317314

Tanyaş M, Günalay Y, Aksoy L, Küçük B. 2013. Disaster logistics management: A new model proposal for Rize. II. Rize Development Symposium Proceedings Book, pp. 256268.

Taylor TK, Sichinsambwe C, Chansa B. 2016. Public perceptions on location of filling stations in the city of Kitwe in Zambia. Developing Country Studies, 6(6): 133-151.

Turğut BT, Taş G, Herekoğlu A, Tozan H, Vayvay O. 2011. A fuzzy AHP based decision support system for disaster center location selection and a case study for Istanbul. Disaster Prevention and Management: An International Journal, 20: 499-520. doi: 10.1108/09653561111178943

TÜİK, 2020. Türkiye İstatistik Kurumu. Adrese dayalı nüfus kayit sistemi. Avaible from: https://biruni.tuik.gov.tr/ medas $/$ kn $=95 \&$ locale $=\operatorname{tr}$ [Accessed 08 December 2020]

UN, 2018. United Nations, Department of Economic and Social Affairs. Revision of World Urbanization Prospects. Avaible from: https://population.un.org/wup/ [Accessed 03 January 2021]

UNHCR, 2007. United Nations High Commissioner for Refugees. Handbook for Emergencies (3rd Ed.). UNHCR, Geneva. Avaible from: https://www.ifrc.org/PageFiles/95884/D.01.03.\%20Handboo k\%20for\%20Emergencies_UNHCR.pdf [Accessed 08 December 2020]

Unal M, Uslu C. 2016. GIS-Based accessibility analysis of urban emergency shelters: The case of Adana city. ISPRS International Archives of the Photogrammetry, Remote Sensing and Spatial Information Sciences, XLII-2/W1: 95101. doi:10.5194/isprs-archives-xlii-2-w1-95-2016

Zhu C, Wang Y, Ren W, Luo I, Yin Y, Xie W, Liu W. 2016. The planning of green spaces to prevent and avoid urban disasters in Dujiangyan. International Journal of Simulation: Systems, Science \& Technology, 17(46): 271-276. doi: 10.5013/IJSSST.a.17.46.27 